\title{
Pembuatan paving blok geopolimer dari limbah abu terbang batu bara (Fly Ash) di Kelurahan Pematang Kapau Tenayan Raya Pekanbaru
}

\author{
Aman* dan Amun Amri \\ Universitas Riau \\ *aman@1ecturer.unri.ac.id
}

\begin{abstract}
Abstrak. Penggunaan batubara sebagai bahan bakar PLTU Tenayan Raya Pekanbaru menghasilkan limbah berupa abu terbang (fly ash) dan abu endapan (bottom ash). Fly ash memiliki kandungan silika dan alumuina tinggi sehingga berpotensi sebagai pengganti semen. Fly ash yang dihasilkan sebagian tidak dimanfaatkan dan ditimbun di ash disposal area dan berpotensi untuk menimbulkan pencemaran air dan tanah. Semakin meningkatnya pemakaian batubara, maka beban lingkungan akan semakin berat dan perlu diantisipasi dengan mencari pemanfaatan secara optimal limbah fly ash batu bara tersebut. Berdasarkan uraian di atas telah dilakukan kegiatan pengabdian masyarakat di Kelurahan Pematang Kapau Kecamatan Tenayan Raya Pekanbaru berupa sosialisasi dan pelatihan pemanfaatan limbah fly ash sebagai bahan pembuatan paving blok geopolimer tanpa menggunakan semen portland yang selama ini dipakai dalam proses pembuatan paving blok dan material bangunan lainnya. Dari hasil kegiatan pelatihan di atas diperoleh paving blok geopolimer dengan spesifikasi bentuk persegi panjang dengan ukuran panjang $21 \mathrm{~cm}$, lebar $10 \mathrm{~cm}$ dan tinggi 8 cm,warna abu-abu dan dari hasil uji diperoleh kuat tekan 40,87 MPa masuk standar SNI mutu A.
\end{abstract}

Kata kunci: fly ash; geopolimer; larutan aktivator; kuat tekan

\begin{abstract}
The use of coal as fuel for PLTU Tenayan Raya Pekanbaru produces waste in the form of fly ash and bottom ash. Fly ash has high silica and alumina content which has the potential to replace cement. The resulting fly ash is partly not utilized and is piled up in the ash disposal area and has the potential to cause water and soil pollution. The increasing use of coal, the environmental burden will be heavier and needs to be anticipated by finding optimal utilization of coal fly ash waste. Based on the description above, community service activities have been carried out in Pematang Kapau Village, Tenayan Raya Pekanbaru District in the form of socialization and training on the use of fly ash waste as a material for making geopolymer paving blocks without using portland cement which has been used in the process of making paving blocks and other building materials. From the results of the above training activities obtained geopolymer paving blocks with specifications rectangular shape with a length of $21 \mathrm{~cm}$, width $10 \mathrm{~cm}$ and height $8 \mathrm{~cm}$, gray color and the test results obtained compressive strength of $40.87 \mathrm{MPa}$ into SNI quality standard A.
\end{abstract}

Keywords: fly ash; geopolimer; activator solution; compressive strength

To cite this article: Aman, \& A. Amri. 2019. Pembuatan paving blok geopolimer dari limbah abu terbang batu bara (Fly Ash) di Kelurahan Pematang Kapau Tenayan Raya Pekanbaru. Unri Conference Series: Community

Engagement 1: 223-227. https://doi.org/10.31258/unricsce.1.223-227

(C) 2019 Authors

Peer-review under responsibility of the organizing committee of Seminar Nasional Pemberdayaan Masyarakat 2019 


\section{PENDAHULUAN}

Pembangunan Pembangkit Listrik Tenaga Uap (PLTU) Tenayan Raya berlokasi di kecamatan Tenayan Raya kota Pekanbaru kapasitas 2 x 100 MW mengkonsumsi batu bara sebanyak 1.000 .000 ton per tahun (Bisnis.com,2017), Hasil dari pembakaran batu bara untuk kebutuhan energi PLTU ini ada 2 macam yaitu fly ash (fly ash) dan aggregat kasar (bottom ash). Produksi fly ash ini akan terus mengalami peningkatan seiring dengan meningkatnya kebutuhan akan batu bara sebagai sumber energi.

Penanganan limbah fly ash (fly ash) oleh PLTU Tenayan ini dibawa ke lokasi penimbunan (landfill). Landfill berupa lubang berbentuk persegi panjang untuk penyimpanan yang dilapisi plastik polyback pada dasar dan dinding lubang tersebut untuk menjaga agar tidak terbawa oleh air hujan, selanjutnya fly ash tadi semakin lama semakin banyak dan akan mengakibatkan pencemaran udara, air dan ekosistem disekitarnya sehingga perlu diantisipasi dengan pemanfaatan secara optimal dari limbah fly ash batu bara (Samadhi et al,2013)

Pada kegiatan pengabdian masyarakat ini diperkenalkan cara pemanfaatan limbah fly ash batu bara sebagai bahan utama pembuatan paving blok geopolimer kepada masyarakat kelurahan Pematang Kapau Kecamatan Tenayan, dimana sumber fly ash batu baranya berasal dari limbah PLTU Tenayan Raya sehingga diharapkan akan terjadi kerjasama yang saling menguntungkan dimana limbah perusahaan dapat termanfaatkan dan dapat mengurangi polusi lingkungan sementara penduduk sekitarnya dapat diberdayakan dengan usaha paving blok atau batako dari limbah fly ash batu bara dari industri tersebut.

\section{MASALAH}

Penggunaan fly ash batu bara sebagai bahan utama pembuatan paving blok geopolimer merupakan metode baru bagi pengusaha/pemilik usaha batako dan paving blok dan juga masyarakat awam sehingga perlu dilakukan sosialisasi kepada masyarakat khususnya kelurahan Pematang Kapau tempat dilaksanakannya kegiatan kukerta terintegrasi Universitas Riau, selanjutnya setelah kegiatan pengabdian ini masyarakat dapat membuat paving blok atau batako geopolimer dari fly ash batu bara tanpa menggunakan semen dan sebagai alternatif mengurangi limbah fly ash yang dapat mencemari lingkungan, disamping dapat menambah pendapatan masyarakat .

\section{METODE}

Sebelum dilakukannya kegiatan pengabdian masyarakat berupa sosialisasi dan pemanfaatan limbah fly ash batu bara sebagai bahan utama pembuatan paving blok dan batako, selama ini para usahawan paving blok dan batako selalu menggunakan semen port land sebagai bahan utama dalam pembuatan paving blok dan batako.

Berdasarkan hasil sosialisasi dan pelatihan pembuatan paving blok dari limbah fly ash batu bara di Kelurahan Pematang Kapau Kecamatan Tenayan Raya Pekanbaru yang dilakukan di tempat warga yang memiliki usaha paving blok dan batako, bersama warga setempat terlihat antusias warga dan juga pemilik usaha paving blok ingin mengetahui bagaimana proses pembuatan paving blok geopolimer tersebut dan apa saja bahan-bahan yang digunakan.

Pada tahap pelaksanaan, kegiatan diawali dengan penjelasan mengenai sifat-sifat bahan baku fly ash, larutan Natrium Hidroksida dan Natrium Silikat serta pasir. Selanjutnya dilaksanakan proses pembuatan paving blok sebagai berikut.

Komposisi bahan baku:

1. Rasio fly Ash terhadap Pasir sebesar $1: 3$;

2. dan rasio $\mathrm{Na}_{2} \mathrm{SiO}_{3} / \mathrm{NaOH}$ sebesar 2,0

3. Konsentasi larutan aktivator $\mathrm{NaOH} 12 \mathrm{M}$,

4. Rasio larutan aktivator/Fly Ash (L/S) sebesar 0,5 temperatur perawatan sebesar $60^{\circ} \mathrm{C}$ selama 24 jam. dan lama perawatan benda uji 28 hari.

\section{Pelaksanaan Pembuatan Paving Blok.}

Pembuatan paving blok geopolimer dimulai dari pencampuran larutan aktivator $\mathrm{NaOH} 12 \mathrm{M}$ dan $\mathrm{Na}_{2} \mathrm{SiO}_{3}$ dibuat 24 jam sebelum ditambahkan pada campuran pasir dan fly ash. Pasir dalam kondisi saturated surface dry (SSD) dan Fly Ash dicampur kurang lebih 10 menit hingga merata (homogen) setelah itu dilakukan penambahan larutan aktivator sambil dilakukan pengadukan selama 15 menit. Kemudian campuran dituangkan ke dalam cetakan atau mesin cetak paving blok. Paving blok yang telah terbentuk lalu disimpan dalam kondisi 
suhu ruang selama 1 hari, kemudian dimasukan ke dalam oven untuk perawatan dengan temperatur $60^{\circ} \mathrm{C}$ selama 24 jam, setelah itu dilanjutkan waktu perawatan 28 hari lalu dilakukan pengujian kuat tekan.

\section{PEMBAHASAN}

Bata beton (paving blok) merupakan salah satu jenis beton non struktural yang dapat dimanfaatkan untuk keperluan jalan, pelataran parkir, trotoar, taman, dan keperluan lainnya. Bata beton terbuat dari campuran semen portland tipe I dan air serta agregat sebagai bahan pengisi. Paving blok dapat berwarna seperti warna aslinya atau diberi zat warna pada komposisinya dan digunakan untuk lantai baik didalam maupun diluar bangunan.

Dari hasil kegiatan pelatihan pembuatan paving blok geopolimer didapatkan produk paving blok geopolimer dengan spesifikasi sebagai berikut:
a. bentuk persegi panjang dengan ukuran panjang $21 \mathrm{~cm}$, lebar $10 \mathrm{~cm}$ dan tinggi $8 \mathrm{~cm}$
b. warna abu-abu
c. kuat tekan $40,87 \mathrm{MPa}$
d. berat $3,864 \mathrm{~kg} / \mathrm{buah}$

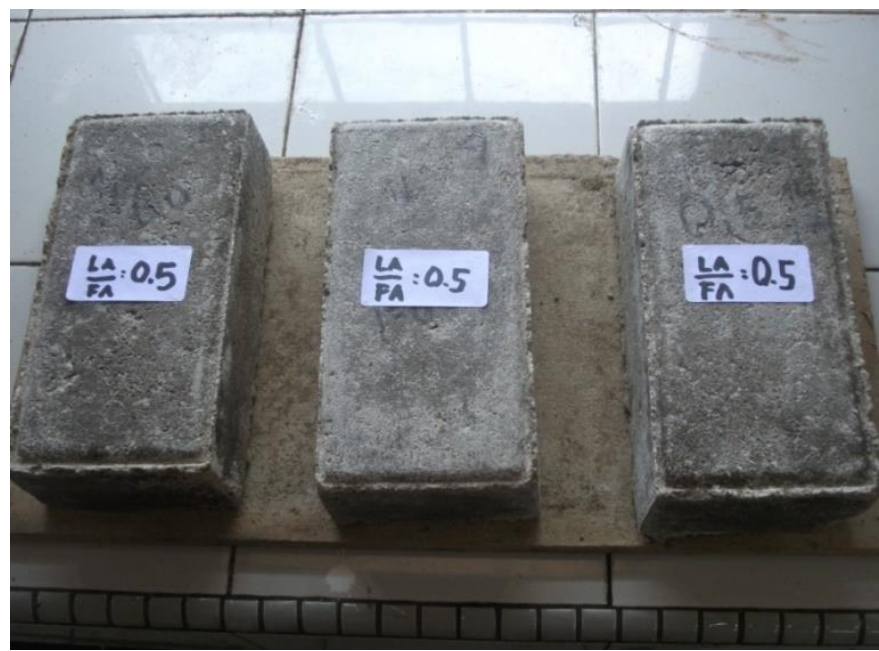

Gambar.1 Paving blok bentuk persegi panjang

Tabel 1. Sifat-sifat fisika paving blok

\begin{tabular}{|c|c|c|c|c|c|}
\hline \multirow{2}{*}{ Mutu } & \multicolumn{2}{|c|}{ Kuat Tekan (MPa) } & \multicolumn{2}{|c|}{ Ketahanan Aus (mm/menit) } & \multirow{2}{*}{$\begin{array}{l}\text { Penyerapan Air } \\
\text { Rata-rata } \\
\text { Maksimum }(\%)\end{array}$} \\
\hline & Rata-rata & Min & Rata-rata & Min & \\
\hline A (Jalan Raya) & 40 & 35 & 0,009 & 0,103 & 3 \\
\hline B (Tempat Parkir) & 20 & 15 & 0,13 & 1,149 & 6 \\
\hline C (Trotoar) & 15 & 12,5 & 0,16 & 1,184 & 8 \\
\hline D (Taman) & 10 & 8,5 & 0,219 & 0,251 & 10 \\
\hline
\end{tabular}

Sumber: SNI 03-0691-1996

Dari hasil pengujian kuat tekan paving blok geopolimer yang dibuat pada kegiatan pengabdian masyarakat yang optimum sebesar 50,87 MPa, dan ternyata masuk mutu A menurut tabel di atas dari sumber SNI 03-06911996. Selanjutnya kelebihan dan kekurangan paving blok geopolimer ini sebagai berikut :

\section{Keunggulan paving blok}

1. Bahan baku utamanya dari limbah fly ash batu bara, tidak pakai semen portland sehingga dapat menekan biaya produksi.

2. Sumber bahan bakunya berlimpah yang merupakan limbah dari pembakaran batu bara dari PLTU Tenayan Raya Pekanbaru. 
3. Dari uji kuat tekan masuk kategori mutu/ kelas A bisa digunakan untuk Jalan Raya sehingga kebutuhan pemakaiannya dapat lebih banyak dibandingkan kelas lain secara tak lasung pemanfaatan limbah fly ashnya lebih banyak.

4. Bila ada kerusakan, perbaikannya tidak memerlukan bahan tambahan yang banyak karena paving blok merupakan bahan yang dapat dipakai kembali meskipun telah mengalami pembongkaran.

\section{Kekurangan paving blok geopolimer}

1. Untuk melarutkan fly ash batu bara sebagai pengganti semen memerlukan larutan kimia seperti $\mathrm{NaOH}$ dan $\mathrm{Na}_{2} \mathrm{SiO}_{3}$.

2. Dalam proses pembuatannya harus memakai alat pengaman diri (APD) seperti masker, dan sarung tangan dikarenakan pemakaian larutan kimia .

3. Memerlukan suhu perawatan sekitar $60{ }^{\circ} \mathrm{C}$ di atas suhu atmosfir.

\section{KESIMPULAN}

Dari hasil kegiatan pelatihan pembuatan paving blok geopolimer dari limbah abu terbang batu bara /fly ash pada Kelurahan Pematang Kapau Pekanbaru dapat disimulkan sebagai berikut:

1. Paving blok yang dibuat dengan komposisi fly ash : pasir (1: 3), aktivator $\mathrm{NaOH} 10 \mathrm{M}$, rasio $\mathrm{NaOH} / \mathrm{Na}_{2} \mathrm{SiO}_{3}$ sebesar 2, suhu dan lama perawatan $60{ }^{\circ} \mathrm{C}$ dan 28 hari

2. Kuat tekan paving blok yang optimum diperoleh 50,87 MPa masuk mutu A

3. Pemilik usaha paving blok/ batako yang selama ini bahan baku utamanya dari semen, berkeinginan untuk untuk mencoba produksi paving blok geopolimer ini dari limbah abu terbang batu bara.

4. Kendala atau kesulitan bagi pengusaha paving blok adalah bagaimana memasok fly ash batu bara ini dari pihak industri karena fly ash ini tidak bisa diambil secara bebas harus ada persyaratan yang harus dipenuhi untuk mengolah fly ash ini sebagai bahan baku disebabkan fly ash masuk kategori B3 yaitu bahan berbahaya dan beracun.

\section{UCAPAN TERIMA KASIH}

Ucapan terima kasih disampaikan kepada Lembaga Penelitian dan Pengabdian Masyarakat (LPPM) Universitas Riau sebagai penyandang dana dalam kegiatan kukerta terintegrasi 2019

\section{DAFTAR PUSTAKA}

Alvarez, E. Ayuso. 2008. Environmental, physical and structural characterisation of geopolymer matrixes synthesized from coal (co-) combustion fly ashes, J.Hazard Matter Vol.154 page 175-183.

Biro Perencanaan Kementerian Perindustrian Republik Indonesia 2012. Perencanaan Kebutuhan Energi Sektor Industri dalam Rangka Akselerasi Industrialisasi.

Budyanto, H. 2012. Pemanfaatan abu sisa PLTU (Fly ash dan bottom ash) dan Pasir sisa Tambang (Tailing) untuk pembuatan bata beton pejal yang aman bagi lingkungan, Tesis UNDIP.

Ciptaningtyas A. L. 2017. https://ekonomi.bisnis.com/read/20170228/44/632401/pltu-tenayan-kapasitas-2x110-mwtelah-beroperasi Diakses pada tanggal 7 Jul 2019.

Ekaputri, J. Triwulan. 2013. Sodium sebagai aktivator fly ash ,Trass dan Lumpur Sidoarjo dalam beton geopolimer, Jurnal Teknik Sipil Vol.20 ISSN 0853-2982.

Hardjito, D. and B.V.Rangan. 2004. Fly ash-Based Geopolymer Comcrete Construction Material for Sustainable Development", invited paper, Concrete World : Engineering and Materials,American concrete Institute, India Chapter, Mumbai, India.

Hardjito, D. and B.V.Rangan. 2004. Properties of Geopolymer Comcrete with fly ash as Source Material: Effect of Mixture Composition", Seventh CANMET/ACI International Conference on Recent Advance in Concrete Technology, Las Vegas, USA.

Irawan. 2009. Metodelogi Penelitian Kualitatif “ Analisis data “ cetakan ke-3 Rajawali Press , Jakarta.

Mishra, A. and Choudhary. 2000. Effect of concentration alkalyn liquid and curing time on strength and water absorption of geopolymer concrete, ARPN Journal of Engineering and Applied sciences Vol.3 no.1 p.87-93. 
Muniz , Bergna J . 2011. The effect of temperature on the geopolymerization process of a metakaolin-based geopolymer. Materials Letters, 65(6),995-998.

Olivia, M.,Putri., Damayanti. 2014. Parametric Study on the compressive strength of Palm Oil Fuel Ash (POFA) Geopolymer mortar. The International Conference on Enviromentally Friendly Civil Engineering Construction and Material, Manado Indonesia.

Samadhi, T.W dan Pratama,P.P. 2013. Synthesis of Geopolymer friom Indonesian Kaolin and Fly Ash as a Green Construction Material, AUN/SEED-Net Regional Conference on Chemical Engineering, Pattaya,Thailand. 